\title{
Functions of English Vs. Other Languages in SRI LANKan BUdDhist RITUALS IN THE UK
}

\author{
Manel HERAT \\ Liverpool Hope University, UK \\ heratm@hope.ac.uk
}

\begin{abstract}
This paper focuses on the functions of English versus other languages in Sri Lankan Buddhist rituals. The framework for this paper is based on a previous work on the language of Hindu rituals by Pandharipande (2012). This study aims to examine the following research questions: (1) What languages are used for practicing Buddhism? (2) Is English used in Buddhist rituals? (3) What methods are used to sanction change? and (4) Will English replace Sinhala and Pali in the UK? In order to answer these research questions, I collected data by attending Sri Lankan Buddhist festivals and event in the UK and recording sermons and speeches used during these festivals to gather information regarding language use and language change. The study proved to be a worthy investigation, as unlike in Sri Lanka where only either Sinhala or Pali is sanctioned in Buddhist practice, in the UK, Sinhala is undergoing language shift and is being replaced by English during Buddhist sermons and other activities. Although prayers and ritual chantings are still in Pali, most of these are explained to the congregation using English. In addition, the use of English is also sanctioned by the Buddhist clergy, through the use of the internet and other media for purposes of promoting Buddhism and reaching young Sri Lankans born in the UK. The investigation draws on Fishman's (1972) theory on domains of language use; Smolicz's (1981) core value theory and Bourdieu's translated work on linguistic markets (1991).
\end{abstract}

Key words: Buddhist rituals; functions of language; English use, Sinhala, Pali, Sri Lankan Buddhists, Buddhist community UK

\section{Povzetek}

Članek se osredotoča na položaj angleščine v primerjavi z drugimi jeziki na primeru budističnih ritualov Šri Lanke. Članek privzema metodološki okvir, ki ga je v svoji raziskavi o jeziku v hindujskih ritualih zasnoval Pandharipande (2012), in poskuša odgovoriti na naslednja vprašanja: 1. V katerih jezikih so izvajani budistični obredi?, 2. Ali so budistični obredi tudi v angleščini?, 3. Kateri mehanizmi se vključijo pri spremembah jezika?, 4. Ali angleščina izpodriva jezika sinhala in pali v Veliki Britaniji. Odgovore na vprašanja je avtor poiskal $s$ snemanjem pridig in govorov na budističnih festivalih in drugih dogodkih po Veliki Britaniji. Rezultati so zelo zanimivi: medtem ko sta na Šri Lanki v uporabi samo jezika sinhala in pali, pa v Veliki Britaniji predvsem sinhalo močno izriva angleščina. $V$ primeru jezika pali pa rituali in molitve ohranjajo prvotni jezik, medtem ko so razlage $v$ angleščini. Angleščino spodbujajo tudi budistični duhovniki predvsem s promocijo budizma preko interneta in drugih medijev.

Ključne besede: budistični rituali; funkcije jezika; uporaba angleščine; jezik sinhala; jezik pali; budisti na Šri Lanki; budistična skupnost v Veliki Britaniji 


\section{Introduction}

There are a large number of Sri Lankan Buddhists in the UK, scattered across many cities of the country with the majority living in places such as London, Birmingham and Manchester. Many of these have come to the UK as professionals or students. It is difficult to estimate the number of Sri Lankan Buddhists in the UK due to inadequacies in the census questions, which does not ask questions about religion and ethnicity. Migrating to a new country is a big experience, and once Sri Lankans come to Britain, they tend to continue their links with Sri Lanka through establishing Buddhist cultural centres and old boy/old girl networks ${ }^{1}$ linked to schools they have attended in Sri Lanka. Cousins (1994:148) notes that the centres founded by Sri Lankan communities became primarily "ethnic centres for the Sinhalese community". The purpose of the Buddhist cultural centres is to promote Buddhism among the second generation of Sri Lankans and to preserve the cultural traditions and Sinhala language.

No previous research exists on the language used for Buddhist practice and rituals in the UK. The only work that discusses a similar topic is Pandharipande (2013, 2010), who analyses the patterns of language use in religious rituals of the Hindu diasporic community in the US, where she observes English is a new code added to the Hindu Community's repertoire of languages of rituals in the US. A study of Sri Lankan Tamils in Melbourne by Fernandez and Clyne (2007) found that among Sri Lankan Hindu families, religious identity was extremely important in maintaining language. They, however, observed that for Christian Tamil families it was their level of educational attainment and their experience of English in the homeland that determined language maintenance or shift. This paper will draw on Smolicz's core value theory (1981, 1991), Fishman's theories of domains of language use and language maintenance (1965, 1966, and 1972) and Bourdieu's theory of linguistic markets to explore the core significance of language in the performance of Buddhist rituals within the Sinhala Buddhist community. As Buddhism is part of the identity of Sinhala Buddhists who have migrated to the UK, the purpose of this paper is to investigate how globalisation and the dominant influence of English have affected the language of Buddhist rituals among the Sinhala community in the UK. This study aims to complement Pandharipande's $(2013,2010)$ work on language use in Hindu rituals in the US by describing and analysing a sample of language use in Buddhist rituals in the UK. It presents findings in the context of how language practices in Buddhism have undergone change to accommodate to the new socio-cultural climate. Following the framework used by Pandharipande (2013) this paper intends to answer the following research questions:

1. What languages are used in Buddhist practice and rituals in the UK?

2. Who sanctions the use of English for Buddhist ritual practice?

3. How is this change sanctioned?

4. Will English replace Sinhala and Pali in the UK?

\footnotetext{
${ }^{1} \mathrm{~A}$ type of society that is based on people with whom one has been to school
} 


\section{Historical Background}

Sri Lankans have continued to migrate to the UK from colonial times, and many Sri Lankans arrived in the UK to work and live after World War II, particularly during the 1950 s and 1960s. Professionals as well as temporary visitors, primarily students came to the UK for studies and began to settle down (Deegalle, 2008:3). According to the 2011 National Census there were 247,743 Buddhists in Britain. However, it is difficult to know exactly how many Sri Lankan Buddhists are there in the UK, as even the Sri Lankan High Commission in London is not able to provide accurate figures on the number of Sri Lankan Buddhists. The UK National Census is of no use in this regard, as it does not include separate questions for ethnicity and religion, classifying all Sri Lankans as 'Asian British' or 'other Asians'.

The Sinhala community in the UK is well represented by Buddhist temples and old boy/old girl networks. The Sri Lankan community regularly gather at temples around the country as well as at people's homes and at the Sri Lankan High Commission in London to celebrate Buddhist festivals and to carry out Buddhist rituals. Buddhist religious festivals are usually also attended by many Sri Lankans who are nonBuddhists as well as non-Sri Lankans. Since Buddhist religious centres are often also cultural centres they gather diaspora Sri Lankans for religious and cultural functions (Deegalle, 2008:10).

\subsection{Buddhism in Sri Lanka}

There are many different sects of Buddhism. Sri Lankan Buddhists practise 'Theravada Buddhism' which means "the view of the elders" (Tilakaratne, 2012:xxiii). The elders are the senior Buddhist monks. Sinhala Buddhists believe that their practice is the closest to the Buddha's original teachings, which were written down in Sri Lanka in the first century C.E (BBC 2002). They were written in Pali and are known as the Pali canon, called the Tipitaka - the three baskets. The three sections are: the Vinaya Pitaka (the code for monastic life); the Sutta Pitaka (teachings of the Buddha) and the Abhidamma Pitaka (supplementary philosophy and religious teaching) These texts have endured without any alterations since being written down and Sri Lankan Buddhists consider it important to commit sections of these texts to memory to be used in Buddhist rituals (Perera, 1988:32; BBC, 2002).

\subsection{Languages in Buddhism}

The Sinhala people speak Sinhala. Sinhala is a diglossic language (Gair, 1968, 1998) with separate spoken and written varieties. The spoken variety consists of formal spoken Sinhala and colloquial Sinhala used in ordinary conversation (Gair, 1998:216) whereas the written variety is more formal and archaic. The spoken variety of Sinhala has borrowed extensively from languages such as Pali, Sanskrit, Tamil and former 
colonial languages, and "is used by all Sri Lankans at all social levels (Senaratne, 2008:28)."

Sinhala is an Indo Aryan language which is supposed to have originated from North India. Sinhala was influenced by many languages, mainly Pali, the liturgical ${ }^{2}$ language of Southern Buddhism and the classical ${ }^{3}$ literary language Sanskrit. Just as Pali was the sacred ${ }^{4}$ language of Buddhism, Sanskrit was the sacred language of the Brahmins, Hinduism and of Mahayanism (de Silva 1981: 59). The Sinhala language consists of equivalent forms from both Sanskrit and Pali, for example, nirvana (Sanskrit); nibbana (Pali). In addition, Sinhala has also been heavily influenced by colonial languages, especially, Portuguese, Dutch and English.

The extensive influence of Pali and Sanskrit lexicon on Sinhala, especially since the arrival of Buddhism in Sri Lanka, can be seen in the Sinhala word stock. The introduction of Buddhism to Sri Lanka is seen by scholars as the beginning of Sinhala culture and Sinhala literature. Ludowyke (1956: 91) describes the impact of Buddhism on the development of Sinhala 'for creative and artistic purposes'. This is supported by De Silva (1981: 57) who cites Buddhism as the greatest stimulus to literary activity among the ancient Sinhalese.

Table 1. shows the population by religion in Sri Lanka and the languages used for religion. As it is evident from Table 1 Buddhism is the most widely practiced religion by the Sinhalese people. Other religions practiced by the Sinhalese include Catholicism and Christianity, which amounts to a total of 7.4 million. Hinduism is mainly practiced by the Tamil population and Islam by Muslims and Malays. In terms of the languages used for religion, Table 1 demonstrates that the languages used for Buddhism are Sinhala and Pali. In Sri Lanka, English is only used for religious purposes by a small group of Sinhala Christians. However, English is a powerful and prestigious language of Sri Lanka outside the religious domain, which is associated with the elite of society. It is seen as a badge of class and is typically referred to as the kadda (sword) (Gunasekera 2005:33); English is also the first language for a small group of people in Sri Lanka and is their home language irrespective of religious affiliation. However, English has been typically excluded from Buddhist practices. Like among the Hindus in India (Pandharipande, 2013:419) English is used for philosophical discourses on Buddhism but not for rituals.

\footnotetext{
${ }^{2} \mathrm{~A}$ liturgical language is a language in which religion is performed.

3 A classical language is defined as a literary language that is no longer spoken except in religious contexts or for ceremonial purposes.

${ }^{4} \mathrm{~A}$ sacred language is defined as a 'holy' or liturgical language that is traditionally used for religious rituals by a community who speaks another language in everyday life, for example, Sanskrit is the sacred language of Hinduism but it is not a spoken language. Hindu worshippers use Sanskrit for worship but Hindi for ordinary conversation.
} 
Table 1: Population by religion and languages used for religion ${ }^{5}$

\begin{tabular}{|l|l|c|l|}
\hline Population & Number (in millions) & $\%$ & $\begin{array}{l}\text { Languages used for } \\
\text { religious rituals }\end{array}$ \\
\hline Buddhist & $14,222,844$ & 70.2 & Pali, Sinhala \\
\hline Hindu & $2,554,606$ & 12.6 & Sanskrit, Tamil \\
\hline Islam & $1,967,227$ & 9.7 & Arabic, Tamil, Malay \\
\hline Roman Catholic & $1,237,038$ & 6.1 & English, Sinhala, Tamil \\
\hline Other Christians & 272,568 & 1.3 & English, Sinhala, Tamil \\
\hline Other & 9,440 & 0.0 & \\
\hline Total & $20,263,723$ & 100 & \\
\hline
\end{tabular}

Source: Sri Lanka Census of Population and Housing, 2011

As Senaratne (2008:29) has noted, Pali and Sanskrit have played an important role in the development of Sinhala and are "visible at all levels, particularly, in the domains of religion, education and administration". Furthermore, she observes, that the Theravada Buddhist scriptures brought to Sri Lanka were in Pali and that it was in Pali that the ancient Sinhalese first started to write. As a result, "a considerable body of writing consisting of exegetical works, religious texts and historical accounts were in Pali and old Sinhalese" (Senaratne, 2008:29). Sinhala developed as a distinct language under the influence of the Pali chronicles and Buddhism (de Silva 1981: 58). Senaratne (2008:209) notes that in subsequent centuries a large gamut of Pali and Sanskrit terms were assimilated into the Sinhala language and that, unusually, many of these forms were retained at least in colloquial form in the language used by the masses. She cites examples such as tanhaavə 'desire' and dharmayə 'doctrine' (among many others), as being commonly used words by speakers of colloquial Sinhala.

Some examples of Pali and Sanskrit borrowings retained in written English in Sri Lanka are illustrated in example (1):

1. The evening pooja and chanting of pirith were done by all at the newly built budu vihara with Ven Sirisumana who did a anumodana of the days kusala kamma. (Newslanka 29th May 2014)

The English sentence in example (1) contains 29 words out of which 7 words are in Pali. This is $24 \%$ of the lexicon, almost a quarter of the words ${ }^{6}$. As noticeable from

\footnotetext{
${ }^{5}$ There is no information available in the census regarding ethnic distribution (for example, \% of Sinhala being Muslims or Catholics, etc. A Sinhala man would only convert to Islam in the event of marrying a Muslim woman. This proportion would be small. The proportion of Sinhalese who are Catholics would be much higher and of the figures given above, it can be surmised that the Sinhalese make up the major portion of Catholics. Tamils are generally Hindus or Muslims.

${ }^{6}$ Pooja means a devotional offering or veneration, pirith is a set of protective chants used by monks as well as lay people; budu vihara can be interpreted as the Buddha's dwelling place, a
} 
example 1, the language used by Sri Lankan Buddhists for ceremonies and rituals is distinct due to the use of Pali. According to Gunasekera (1891:381) a few examples of the most commonly used Pali and Sanskrit terms that characterize language used for Buddhist rituals by a Sinhala speaker are sil 'meditation', pooya 'full moon day', nirvaana 'enlightenment', dhamma 'doctrine', teeroo 'a Buddhist monk' and dukka ' sorrow'. Senaratne (2008) sees these Pali terms as conveying "reverence and respect".

\subsection{Buddhist ceremonies and rituals}

Kariyawasam (1996:2) notes that any religion when it is introduced to a new cultural context needs a 'communally shared' system of outward manifestations of practice to express people's devotion to the religion. He further recognises Buddhist ceremonies and rituals as necessary 'devotional forms' for the survival of Buddhism as a vital and vibrant force in society. In both Sri Lanka and in other countries, Sri Lankans practice Buddhism by performing certain ceremonies, rituals and devotional practices.

A ritual is defined as "as an outward act performed regularly and consistently in a context that confers upon it a religious significance not immediately evident in the act itself". A ceremony on the other hand is "a composite unity consisting of a number of subordinate ritualistic acts" (Kariyawasam, 1996:3).

Buddhists rituals and ceremonies performed by Sri Lankan Buddhists can be broadly classified according to three headings:

a. Acts performed for the acquisition of merit (offering of food to the monks, alms giving, Pali: punnkamma; Sanskrit punyakarma)

b. Acts directed towards securing worldly prosperity and averting calamities through disease and unseen forces. Pirith chanting; Bodhi puja

c. Rituals adopted from folk religion. (superstitions, horoscopes)

Kariyawasam (1996) observes that all religious activities that have a ceremonial and a ritualistic significance in Buddhism are regarded as acts for the acquisition of merit. In this sense, all Buddhist religious activity can be explained as a means towards this end.

place of worship, anumodana is a kind of thanksgiving through which merit is transferred and finally kusala kamma means good deeds. 


\section{Theoretical background}

\subsection{Core value theory}

The theoretical background for this paper is drawn from the sociology of language that examines core values as crucial for cultural identity. The theory of the core values of culture (Smolicz 1981) has been shown to be useful in understanding patterns of language maintenance, change and language loss in multilingual societies. According to Smolicz (1981:108), the maintenance of a group's language and culture depends on the extent to which its heritage interacts with new cultural inputs. This theory can be applied to the way in which language is used within the Sri Lankan Buddhist community; as Smolicz observes, cultural values are not just a random collection of items that are of equal value to a group's cultural identity, but are aspects of cultural identity which are of "fundamental importance for its continued viability and integrity that they can be regarded as the pivots around which the whole social and identificational system of the group is organised."

For Smolicz (1981:109) core values are cultural values from the homeland which symbolically identify the group and its membership. He observes that it is through core values that social groups can be identified as distinct communities who can maintain their own creative culture. Core value theory becomes fundamental in the circumstances discussed here where there are external pressures for language change due to globalisation and the new cultural context. It has been argued (Smolicz, 1991) that cultural groups differ in terms of the extent to which they emphasise their own language as a core value. In relation to the Sri Lankan Buddhist community, it could be stated that the Sinhala language and the Buddhist religion are core cultural values that define the identity of the Sinhala Buddhist community in the UK. Nevertheless, due to external pressures from the new cultural context and processes of globalisation, Sri Lankans have adapted English in performing various non-core tasks at Buddhist functions. Although the Pali language is still used for chanting prayers and for performing the rituals, English is recognised as suitable for other activities for which Sinhala would normally be the language used in the homeland. The inclusion of English and change in language functions is discussed below using Fishman's (1972) notion of domains of language use.

\subsection{Domains of Language use in Sri Lanka}

In his classic study of the New Jersey barrio, Joshua Fishman (1972) laid down some useful generalizations that will be adapted in this discussion. Fishman defines a domain as a social space, such as home or family, school, neighbourhood, church (or in this case temple), workplace, public media, or government. He further distinguishes a domain by three characteristics: participants, location, and topic. The social roles and relationships of participants characterise a domain not individuals. These relationships can sometimes cause obvious conflicts. What is evident from 
Fishman's theory however is that the choices made by individuals depend on people's understanding of what language(s) are appropriate for a particular domain.

\subsubsection{Use of Sinhala}

In Sri Lanka Sinhala is the only language that is used in the religious domain for nonritual activities. It would have a significant use in the religious domain compared to formal domains. For most people, Sinhala would also be the language used at home and at the temple. In the Sri Lankan context Sinhala seems to be exchanging places with English in many formal domains. In domains where Sinhala dominates such as at the temple, English would have no role. This indicates that in Sri Lanka English is an alternate code for Sinhala.

\subsubsection{Use of English}

As mentioned above, English is more evident within formal domains such as educational, professional contexts, etc. In Sri Lanka English would be the least used code in the religious domain, especially among Buddhists, Muslims and Hindus. It is common for Catholic and Protestant services in church to be held in English. This indicates that English has a prominent role in daily discourse, especially in education and in professional contexts but not in religious domains.

\subsubsection{Use of Pali}

According to Fernando (1977:343) the clergy of all three oriental religions in Sri Lanka (Buddhist, Islam and Hindu) would normally know no English (the rare exception being the missionary Buddhist monk or Hindu priest). All Buddhist sermons are preached in Sinhala, but the language of the sacred texts is Pali and all ritual chanting and prayers would be in Pali.

\section{Methodology}

The data analysis will consider the use of language in two important rituals: the rain retreat and the Sinhala New Year celebrations. These Buddhist rituals are performed both at Buddhist temples and organisations in the UK.

The data for the investigation was collected through participant observation and recording of events; recordings were made of 5 speeches and 5 sermons at the Sinhala New Year celebrations and the Rain Festival during 2013 held at Manchester, Letchworth, Leicester and London. The speeches were approximately 20-30 minutes long and the sermons were approximately 40 minutes to 1 hour in duration. Each of the sermons and speeches on average contained 5242 and 2664 words respectively. The total number of words for the recorded data are 39,533. The data are also supplemented from a newspaper corpus covering a time span of one year from the publication NewsLanka, an English newspaper produced in the UK in order to see how the media uses language to authenticate Buddhist rituals. The total number of words 
of the newspaper corpus is 257,388 . The corpus included all articles not only ones related to the reporting of Buddhist rituals.

The transcripts of the recorded data were analysed using AntConc (version 3.4.1w developed by Anthony (2014)) with regard to keyword use. Although not entirely comparable, for this I used the Newslanka corpus as a reference corpus to investigate what languages the top 5 key words in the recorded data are in. This method was used to reveal what languages were most prominent within Buddhist rituals in the UK. The analysis is mainly qualitative but data will also be presented quantitatively with regard to key word use. As the two corpora are not comparable in terms of the number of words, normalised frequencies will be provided per thousand words.

\section{Findings}

\section{1 . English in Buddhist rituals in the UK}

The findings from the participant observation confirmed that English is being used at Buddhist festivals, especially for sermons but not for pirith chanting or prayers. The chanting was always in Pali, but after the chanting was over explanations of the chanting were given in English, whereas in Sri Lanka usually these explanations would be in Sinhala. This is confirmed by Deegalle (2008:18) who observes that "the programmes of the $\mathrm{SSIBC}^{7}$ are conducted both in Sinhala and English". In terms of the interaction among lay people and clergy, a clear pattern was evident with regard to language domains. The use of language among interlocutors is detailed in Figure 1. The percentages are calculated by looking at the duration of time used for each language.

It was found that all talk with the Buddhist priests are in Sinhala, whereas conversation among friends is either in Sinhala, English or a Sinhala/English mixed code. The mixed code was more predominant than Sinhala. Young people (second generation) usually used only English to talk to their parents; the parents used Sinhala, or sometimes a mixed Sinhala/English code to talk to their children. The patterns of language with one's spouse were also sometimes wholly in Sinhala, at other times, in both Sinhala and English. However, unlike Pandharipande's (2013) study, no English was used at ritual events by Sri Lankans for purposes of chanting and prayers. These were always observed in Pali. The findings suggest that religion has a strong influence on language maintenance. Sinhalese who are devout Buddhists are likely to use Sinhala for politeness in addressing the Buddhist priests and for

7 This is a Sri Lankan organisation The Sri Saddhatisa International Buddhist Centre in London.

There is no information available in the census regarding ethnic distribution (for example, \% of Sinhala being Muslims or Catholics, etc. A Sinhala man would only convert to Islam in the event of marrying a muslim woman. This proportion would be small. The proportion of Sinhalese who are Catholics would be much higher and of the figures given above, it can be surmised that the Sinhales make up the major portion of Catholics. Tamils are generally Hindus or Muslims. 
philosophical and political discussions. This confirms similar findings by Fernandez and Clyne (2007) carried out in Australia, who observed that Indian and Sri Lankan Tamils who are Hindus have the lowest rate of language shift compared to people of other religious affiliations.

Figure 1: Language use in different domains

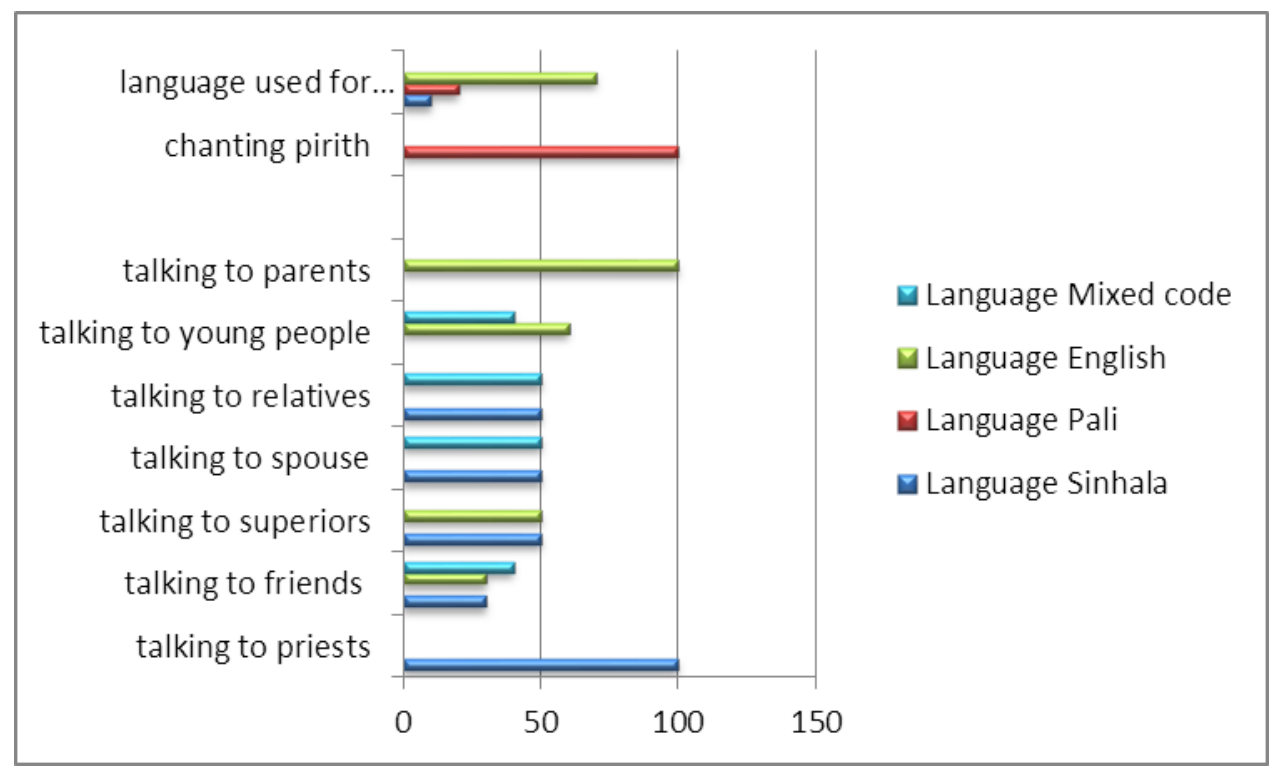

\subsection{The rain festival}

"The rain festival is a three month religious retreat called vassa (rain) which ends with the offering of kathina ('hard') robes to the community of monks and is an extremely important religious event for the communal life of Theravada Buddhists in South Asia and Southeast Asia" (Deegalle, 2008:7). The observance of the rain retreat is an age old tradition, and is directly related to the weather pattern. In Sri Lanka, this ceremony is performed after the full moon day in October at the end of the rainy season. The ritual is performed by taking the robes "in a colourful procession, accompanied by local traditional dancing, music, decorations, flags and floral arrangements" (Tilakaratne, 2012:98) around the village in the early hours of the morning. Once the offering of the robes is done, "certain monks are selected to do the cutting, sewing and dying of the robes - all in a single day" (Kariyawasam, 1996). In the UK, although it may not be the rainy season, the ritual is still performed to enable people to learn and practice dhamma. The ritual of going in procession to the temple with the robes was only performed in one location; in the other places, the procession was held in a function room.

With regard to language use, invitations to the ceremony are sent out via email in English but the subject of the email was sometimes entitled in Sinhala Vas Aradhana (rain invitation) and the ritual itself was referred to as the katina chivara (rain festival) 
and the period of time was referred to as the vassana (rain).The congregation and the members were referred to using the terms dayaka dayikas (male and female devotees) which can be seen as an Anglicization of the Sinhala words dayikavo (female, -pl); dayakayo (male, -pl). Gunasekera (2005:195) defines it as a "Sinhala term to refer to people who assist the priests in the running of the temple." References to the clergy are made through use of the words maha sangha (clergy). Although the words katina chivara (rain retreat) was used, equivalent English forms 'rain retreat' or 'rains retreat' was also used to refer to the ritual. In performing the ritual of offering 'cloth' to the Buddhist monks who observed the retreat, announcements at the ritual were in English not in Sinhala.

The continued use of Pali in ritual chantings can be seen as a recognition that the survival of the Sri Lankan Buddhist community remains in the preservation of the cultural identity and maintenance of the sacred language of Buddhism, as observed in Smolicz's core value theory. The core significance of language in the transmission of culture is seen by the fact that Sinhala continues to be used in spoken interaction among family and friends but there is also a preference for English for activities that are not seen as 'core' cultural activities. This may be an attempt to be inclusive of non-Sri lankans and non-Buddhists or it may be that using English is easier or an acceptance of the status quo. Fishman's $(1965,1966)$ observation that it is characteristic of immigrant groups to move from a non-English language to English monolingualism is not evident here as bilingual language use is a more noticeable aspect with English taking over certain functions of Sinhala.

\subsection{Language use during the New Year celebrations}

According to the lunar calendar, Sri Lankans celebrate the New Year festival usually in the middle of April by observing a number of domestic rituals. In the home country, these rituals are shared by people in the neighbourhood and the New Year is celebrated by sharing food, music, dance and traditional sports. In the UK, it is not possible to celebrate the Sri Lankan New Year within this same cultural context. In order to get a sense of community, the New Year is celebrated at Buddhist temples or in a hired function room with the Buddhist monks chairing the proceedings. This is a major difference to how the New Year is celebrated in Sri Lanka. This not only changes the ritual of how the event is celebrated but it also influences language use. The proceedings usually begin with the arrival of the Buddhist priests and the lighting of the traditional lamp and the singing of the Jayamangala Gatha ${ }^{8}$ by young girls clad

8 The recital of the jayamangala gatha, is "a set of eight benedictory stanzas extolling the virtues of the Buddha." This is usually done on important occasions like a marriage ceremony, when setting out on an important journey, or when inaugurating any venture of significance. According to Kariyawasam (1996)The contents of the stanzas recited clearly show that the ritual is intended to bring happiness and prosperity to the persons concerned or the successful completion of the project. Accordingly these verses have come to be called "the stanzas of success and prosperity," Jayamangala Gatha, and have become quite popular among all sections of the Buddhists. 
in white saris. Then the chief priest of the temple welcomes the congregation in English. In Sri Lanka, Buddhist priests would always address the congregation in Sinhala. After the welcome, there is a sermon by a priest before the day's events begin. The priest usually quotes what he refers to as 'a teaching' from the Maha Parinibbana Sutta from the Digha Nikaya in English. As Deegalle notes (2008:17) an important aspect of this diaspora Sri Lankan community is that" it attempts to be inclusive by integrating into British society by involving local authorities in Buddhist ritual activities", which may be another reason for the use of English.

\subsection{Qualitative data analysis - samples of language use in Buddhist rituals}

In the following section, I will consider some samples of language from the recorded data to illustrate the functions of English and other languages in Buddhist rituals.

As example (2) demonstrates, although English is used for the teaching, Pali words for important Buddhist concepts are mentioned by the monk:

2. According to this well known discourse, the Buddha once addressed Ananda and said: "Ananda, whoever has developed four paths of power (iddhipada), practised them frequently, made them his vehicle, made them his base, established them, become familiar with them, and properly undertaken them, he could undoubtedly live for a century (Ayukappa) or the remainder of one. The Tathagatha has developed these powers..."

In the sermon in (2), the priest explains the Buddhist concepts in English and then provides the Pali words, iddhipada and ayukappa. In Buddhism, the word iddhipada refers to factors that are "critical in accomplishing a goal, whether mental or transcendental." Iddhi means magical powers to see and hear things and to be able to read minds. Pada refers to the base. In other words, iddhipada gives the meaning of 'power' which includes will power, effort, consciousness and wisdom. Ayukappa on the other hand suggests duration of life, in this case a century. As the core value theory suggests using Pali words for Buddhist concepts and quoting from the Sinhala Literary Canon while preaching could be seen as a way of maintaining a distinct cultural identity. The function of Pali/English, Sinhala/English in examples (2), (3) and (4) draw on a bicultural/biliterate identity and takes advantage of the religious and cultural values of Sri Lanka.

Likewise, the opposite is also present where the Pali words are given first and then they are explained in English as in example (3):

3. What then are these four-fold paths of power? They are chanda (intention or wish) citta (consciousness), viriya (effort or energy) and vimamsa (investigation).

In example (3) four Pali words are used. Chanda is explained as intention. In Buddhism chanda is recognised as a mental feature that can have positive or negative 
effects depending on what factors it co-occurs with. In the sermon, the monk is careful with his choice of words. The word citta is used as opposed to the words manasa and vinnanaya all of which are used in Pali and Sinhala in a generic sense to mean 'mind'. According to the Pali Text Society's Pali-English dictionary, the word citta emphasises the emotional or conative side of the mind being referred to as heart (psychologically), whereas the word manasa on the other hand emphasises the intellect. Cita is defined as "the centre and focus of man's emotional nature as well as that intellectual element which inheres in and accompanies its manifestations; i. e. thought". Viriya, on the other hand is translated as expending effort or energy as mentioned in the sermon and can be defined as "having an attitude of engaging gladly with wholesome activities". Vimamsa is described as investigation and is used to mean "skilfulness or wisdom".

It is also common for the Buddhist priest to quote from the Sinhala literary canon and verses from works such as the Lowedasangarawa are utilised in English for purposes of explaining ideas (see example (4):

4. "when one does an evil deed it may feel like eating honey, but when the results of such actions come it will feel like eating fire".

In example (4), the priest uses some new similes such as comparing the doing of an evil deed to the 'feeling of eating honey', which suggests something pleasant and sweet but the result of the evil deed is compared 'to eating fire' which suggests an unimaginable and horrific outcome.

The Dhammapada is also quoted as in example (5), and in these translations conditionals are used with similes to foreground important considerations. In example (5), it is said that 'if someone acts with an impure mind, then their pain will pursue them and this is symbolised by 'the wheel that follows the foot of the ox'. The ox is a beast of burden and the wheel following the ox indicates relentless action that has no end. On the other hand, in example (6), if a person acts with a pure mind, the simile used to describe their happiness 'never departing shadow' suggests that happiness is a constant companion for those whose acts are 'pure.'

5. "If with an impure mind a person speaks or acts, suffering follows him like the wheel that follows the foot of the ox".

6. "If with a pure mind a person speaks or acts happiness follows him like his never departing shadow".

English is also used for thanking the congregation. Hybrid compounds using Sinhala and English are used such as sugatha qualities to describe the good qualities of those who help the temple and the Buddhist monks. The word sugatha in Pali means Buddha, so using this word as a modifier for the word 'qualities' indicates that the people in question have 'Buddha qualities' or the qualities of a Buddha.

The Buddhist monks' language use also suggests that they have to be very careful when they translate Pali words into English because there are no clear equivalents that convey the actual meaning of the Pali words. Example (7) demonstrates that 
there is no direct equivalent for the word avija although it is often translated as ignorance. This example shows the way in which the Buddhist monk tries to explain it in English.

7. "Avijja, Pali word Avijja translates as ignorance into English. What is the real meaning? If I say ignore, is it the same meaning or a different meaning? [waits for answer from the audience] It is different meaning. So the ignorance has the lack of knowledge as well meaning. Original meaning. Then it is right. Avijja also has the same meaning. One is don't know, that is lack of knowledge. I don't know. Another thing, ignoring. I know but I don't want to know, that is ignoring. Avijja. Sometimes people they don't know what is actually happening; other things they know but they don't want to know. "

The monk goes on to further explain the concept using real life examples looking at how people react to a doctor's advice about disease. Through these means he is able to explain what he sees as a difficult Pali word for people to understand. There are also times when the monk is unable to explain a particular word in English, such as in example (8).

8. For the monks, the Buddha advised; when you walk don't look at here and there like this. In Sinhala we say viyagasa. I don't know what is the English word for this? What is the word? Don't look here and there?

The above analysis illustrates that the inclusion of English has changed the linguistic repertoire of the Sinhala Buddhist Community in the UK. As noted above, in the homeland all Buddhist sermons are preached in Sinhala, but the language of rituals is Pali. In the rituals discussed above, priests use Sinhala, Pali and English and not just Sinhala or Pali. As with Hindu priests, using English only for performing rituals is uncommon. The priests generally use English for translation purposes and for explanation, especially for those who have no knowledge of either Sinhala or Pali. However, the priests are known to also give sermons in English and things like announcements, emails, texts, messages, newsletters, etc., are in English. Even though the use of Sinhala is a core cultural value that defines Sinhala Buddhists, external pressures from the new context such as integration has made it essential for English to be recognised as an important language of communication in the religious domain.

The analysis of language use suggests that the inclusion of English in the linguistic repertoire has changed the repertoire of the Sinhala Buddhist community as well as the structure of the language of Buddhism. English has taken over the function of Sinhala in the religious domain of sermons, explanations of rituals, messages, newsletters, announcements, and philosophical discussions as it is the dominant language spoken by the majority of people in the UK. 


\subsection{Quantitative data analysis - language use in Buddhist rituals}

\subsubsection{Most frequent words}

Having considered how language functions in Buddhist rituals in the UK qualitatively, I will now provide a quantitative analysis of the data examining the most common words in the two corpora and the key words in the recorded data. Table 2 demonstrates that Buddhist terms are more common in the recorded transcripts than in the Newslanka corpus although some terms appear to feature more in the Newslanka corpus such as 'dhamma school'. It is also interesting that the terms 'venerable, 'Buddhist' and 'monks' were used less in the Newslanka corpus whereas its use in the recorded data was higher. This could be because the speeches included a long list of Buddhist priests who were welcomed to the events in question. The log likelihood score suggests that the term 'resident/venerable Buddhist monks' was overused in the transcript corpus with a score $0.57 \%$ compared to the newspaper corpus which was $0.23 \%$ giving a total log likelihood calculation of 382.64 , which is statistically significant. Of the most frequent words per 1000 words, 'meditation retreat' and 'rainy retreat' had the highest frequency in the recorded data (5.72) as opposed to the newspaper data(0.23). The fact that the English words 'meditation' and 'rainy retreat' are used as opposed to their Sinhala equivalents bhavana and kathina reveals that English has a higher functional use within Buddhist rituals than Sinhala.

Table 2: Words with the highest frequency per 1000 words in recorded and newspaper data

\begin{tabular}{|l|c|c|}
\hline Sri Lankanisms & $\begin{array}{c}\text { Frequency of use per } \\
\mathbf{1 0 0 0} \text { words } \\
\text { recorded data }\end{array}$ & $\begin{array}{c}\text { Frequency of use per } \\
\mathbf{1 0 0 0} \text { words } \\
\text { newspaper data }\end{array}$ \\
\hline dhamma school & 3.66 & 3.31 \\
\hline dhamma sermon & 3.31 & 0.04 \\
\hline Buddha puja & 2.31 & 0.02 \\
\hline Resident/venerable/Buddhist monks & 5.72 & 0.23 \\
\hline Meditation/rainy retreat & 5.72 & 0.23 \\
\hline
\end{tabular}

\subsubsection{Keyword analysis}

The keyword analysis of the recorded transcripts showed that the 5 most frequent words that were used in Buddhist rituals were the words dhamma, Buddha, vihara, meditation and mind. This shows that in terms of language use Pali is the most frequent and then English. The fact that no Sinhala words are used in the top 5 key words suggests that English is replacing Sinhala in Buddhist rituals. The frequencies are given in Table 3. 
Table 3: The five most frequent keywords in the recorded data

\begin{tabular}{|l|c|c|}
\hline $\begin{array}{l}\text { Keywords used in the } \\
\text { transcripts }\end{array}$ & Frequency & Keyness \\
\hline Dhamma & 295 & 1055.536 \\
\hline Buddha & 287 & 1034.948 \\
\hline Vihara & 202 & 516.759 \\
\hline Meditations & 97 & 253.111 \\
\hline Mind & 94 & 226.608 \\
\hline
\end{tabular}

\section{Discussion}

\subsection{What languages are used in Buddhist practice and rituals?}

The findings show that language use among the Sri Lankan Buddhist community is complex with Pali, Sinhala and English interacting at different times for Buddhist practices and rituals. As a practice, English is used among Sri Lankans for non-religious cultural activities and it is not clear that there is disapproval for this use, although there may very well be some Sri Lankans for whom this may not be acceptable.

Bourdieu's translated work (1991) on linguistic markets offers a new way of understanding the differential values assigned to English and other varieties or languages. Bourdieu associates language skills and knowledge with various kinds of 'symbolic capital' and distinctive life styles. His concept of 'symbolic capital' is useful in understanding the hegemony of English. In Bourdieu's view, 'linguistic hegemony' is an integrated market with sponsorship from the state. This theory raises two important issues: firstly, the role of state cultural institutions in reproducing the hegemony of the legitimate language (here read as English) over other co-existing languages (here read as Sinhala and Pali), and secondly, the extent of integration that is, to what extent hegemony is fully established and to what extent these markets allow the production and maintenance of alternate languages. In relation to English and Buddhist culture, using Bourdieu's notion of language and symbolic power, it could be said that English is the dominant language in the secular domain, as it is the language of work, education, commerce, etc., whereas in the religious domain, English has less power. In the context of the UK, it is the main language in both religious and secular domains, including those of Christianity and Judaism.

Among Buddhists, although English is used for sermons and for explaining Buddhist concepts and philosophical ideas and for quoting from the Dhammapada, it is not used for conversing with the Buddhist priests nor for religious chanting and prayers, which are always in the liturgical language Pali. Sinhala is used for purposes of discourse and for interacting with the Buddhist priests. In Sri Lanka, Buddhists priests are highly respected and there are special terms for addressing a Buddhist 
monk and for rituals associated with Buddhist monks such as sitting, eating, walking, dying, etc. (see Table 4)

Table 4: Special terms used by lay people when talking to the clergy

(Also see Senaratne, 2008:39)

\begin{tabular}{|l|c|c|}
\hline Meaning of the words in English & $\begin{array}{c}\text { Words in } \\
\text { colloquial Sinhala }\end{array}$ & $\begin{array}{c}\text { Special terms } \\
\text { for Buddhist clergy }\end{array}$ \\
\hline Eating & kanava & valadinava \\
\hline Drinking & bonava & valadinava \\
\hline Sleeping & nidagannava & saethapenava \\
\hline Food & aahara & daanaya \\
\hline coming in & enava & vadinava \\
\hline Died & nethivuna & apawathvuna \\
\hline Preaching & kiyanavaa & deeshanaa karanava \\
\hline yes (in answer to question) & ov & ehemai, ehei \\
\hline yes (in answer to request) & haa & hondamai \\
\hline present (as in the priest is in the temple) & innawa & vedainnava \\
\hline
\end{tabular}

As seen from Table 4, when a Buddhist monk is invited to enter a place the word is vadinawa not the normal term that is used to ask a person to come in which is enna. Likewise, it's not possible in Sinhala to say a monk is eating or drinking, one has to say valadinavaa. As Buddhist priests are highly respected in society, a lay person would also not sit down at the same level with a priest nor will they partake of food at the same time as the monks. These customs are preserved in Buddhist practice in the UK and in order to be able to perform this kind of humility in discourse, the appropriate language is Sinhala. I observed very little direct interaction between second generation young people and clergy although I did find that when they did interact they used English but addressed the clergy in Sinhala using the word hamuduruwane which is a respectful way of addressing a monk in Sinhala. Nevertheless, one can agree with Deegalle that the second generation is not as close to the Buddhist clergy and the community (Deegalle, 2008:29) as the first generation is nor is the relationship the same as it would be in Sri Lanka. A distance is created between the clergy and the second generation because of the language barrier.

English is regarded as a prestigious language in Sri Lanka and attitudes towards English are quite positive. Unlike Indians, who often prefer to use their own mother tongue, the Sinhala people prefer to be seen as being able to use English. This ties in with notions of social class and prestige and could be a reason why it is seen as acceptable to use English in Buddhist practice; often, non- Buddhists and non-Sri Lankans also attend these events, and using English is a means of being inclusive and 'accommodating' towards outsiders. Unlike other religions it also posits Buddhists as being liberal. 


\subsection{Who sanctions the use of English?}

The above discussion raises the question, namely, who authenticates or sanctions the change in the patterns of language use for English in Buddhist practice and rituals, and what is "the method" through which this change is authenticated? Before discussing these questions, it is pertinent to explain the nature of 'authority' in Sri Lankan Buddhism. As Pandharipande (2013:423) explains for Hinduism, in Buddhism too, there is no central authority such as the Church in Christianity. The main source of authority is the Buddhist clergy; they are held with high reverence and respect. Therefore, like the Hindu Saints and Mystics, traditionally, the Buddhist clergy have always been regarded as the quintessential authority "to introduce, sanction or prohibit certain religious practices and rituals (Pandharipande, 2013:423)." From the pre-colonial period the temples were the centres of learning and it was the monks who provided people with formal education. Hughes (1987) observes that as the sole teachers and knowledge producers of their society, the monks shaped the world views of the people in their own interests, and in the interests of those with whom they were inter-dependent, the aristocracy and royalty. This ties in with Bourdieu's notion of who provides linguistic authority, as he (1991:63) mentions schools, schoolmasters, the grammarians and the literary producers as those who inculcate recognition of linguistic authority. He notes that even though it is the family that first endows the child with language, it is the school system that establishes and legitimises the most highly valued linguistic and cultural forms, and secures universal recognition of this legitimacy. In the case of Buddhism, because of the authority of monks as providers of education they hold the authority to decide which languages can be used. Even today there is a close relationship between the community and the Buddhist clergy and people look up to the clergy as teachers and guides, and as a result, they are highly revered. The Buddha's teaching, the Dhammapada is regarded as the equivalent of the Christian Bible. This is seen by the fact that in five star hotels in Sri Lanka, a copy of the Dhammapada is available alongside the Gideon's Bible.

When we examine the Buddhist clergy in the UK, it is clear that it is on their authority that English use is authenticated. The Buddhist clergy who head the Buddhist temples are monks who have arrived from Sri Lanka. Although Fernando (1977) claimed that Buddhist monks normally have no knowledge of English, this is no longer true for Buddhist monks who take up residence in temples outside Sri Lanka. Their knowledge and proficiency of English is on a continuum with some monks being highly proficient in English and others not having such a high level of proficiency. As mentioned before, in Sri Lanka English is typically excluded from Buddhist rituals, however, this is not the case in the UK, where the clergy encourage devotees to practice Buddhism using whatever language they are comfortable in.

\subsection{How is this change sanctioned?}

As seen in the findings, the degree and extent to which English is used in Buddhist discourse is limited as it does not infiltrate or encroach on ritual chanting or 
Dhammapada which are in Pali. At many of the Buddhist temples, the chief priests as well as most other clergy use English in their sermons and discourse and the degree to which English is used among the different monks varies depending on their own proficiency as well as the topic and the audience. A noticeable feature of my participant observation was that more English was used when the audience included young Buddhists, especially teenagers, and if the topic of the sermon referred to aspects such as sexuality and crime. Sexuality is a taboo topic in Sinhala, which is often avoided by the Sinhalese and this may possibly be another reason for the increased use of English. Another reason for using English was if the audience included non-Sri Lankans or young people.

\subsection{What are the methods used to sanction language change?}

The media (including newspapers, YouTube and the internet) contribute to the sanctioning of language change. Newspapers report Buddhist events using the same words in English used by Buddhist monks albeit in a more standard form than in speech. You Tube is a powerful new media that is used for this purpose; sermons are publicised through YouTube in English, to consolidate and bring together the Buddhist community. Most Sri Lankan Buddhist temples in the UK also have internet websites through which people can listen to Buddhist chanting and sermons or even contact the priest to ask a question. This relates to the issue of what variation is permissible in Bourdieu's linguistic market and the attitudes towards alternative linguistic forms. Bourdieu argues that there are no linguistic markets which are so fully integrated that there are no private markets where variant forms could be used, and where standards are relaxed.

The sanction of English for Buddhism by Buddhist monks is also seen through the publication of chantings and prayers in English, through the medium of e-books and CDs. The following e-book Vandana: the album of Pali devotional chanting and hymns written by a senior Sri Lankan monk Elgiriye Indraratne gives the English translations for all ritual chantings for different occasions and this e-book is made available through Sri Lankan Buddhist temple websites in the UK. The e-book further provides the email address and a website link for devotees to contact the priest. The book has been produced by the Buddha Dharma Education Association. The first page of the book tells devotees about ' 3 objects of veneration in a Buddhist temple' and gives instructions on how to venerate those objects, for example: "Veneration can be carried out by reciting the appropriate stanzas and making some offerings like flowers, incense and oil". The stanza to be recited is given in (9):

A popular stanza in venerating the three objects is:

9. Vandāmi cetiyam sabbam

Sabbatțhānesu patițthitam

Sārīrikadhātu Mahā-Bodhim

Buddharūpaṃ sakalam sadā 
I salute every Stupa

that stands in any place,

the bodily relics,

the great Bodhi Tree and

All images of the Buddha.

This is an example of how the use of English as well as Pali devotional chantings is authenticated. This accommodation of English and non-Pali chants for use in performing rituals is important, as it sends the message to those Sinhala Buddhists whose first language is English, and most importantly, the Sri Lankan community in the UK, that the Buddhist clergy sanction the use of English as well as the mixed code in Buddhist practice.

In addition, there are also numerous websites, newsletters, YouTube sermons, etc., that have been authenticated by the Sri Lankan Buddhist clergy that provide Buddhist devotees with the necessary chantings and prayers for use in their homes or temples. This is quite an important change for Sri Lankan Buddhists that would not be witnessed in Sri Lanka, where Buddhism is heavily 'guarded' in its original liturgical language.

Example (10) is a hymn from a Buddhist music CD Abhaya Gatha devotional hymns for blessings and protection by Gee Bees. It was published and produced by the Mahindarama Temple in Malaysia in collaboration with Elgiriye Indraratne, a senior Sri Lankan monk. The song is in English and Pali and uses a traditional Asian style of music.

10. Buddham Saranam Gacchāmi

Dhammam Saranam Gacchāmi

Sangham Saranam Gacchāmi

I go to the Buddha as my refuge

I go to the Dhamma as my refuge

I go to the Sangha as my refuge

$$
\begin{aligned}
& \text { Ah - ha - ha - ha - ha ha ha ha ha - ha } \\
& \text { Ah - ha - ha - ha - ha ha ha ha ha - ha }
\end{aligned}
$$

Many religions have found ways to transfer their rituals into a virtual format; Pandharipande (2013:425) notes that Hindus can perform the worship ritual virtually by simply clicking on the name of the 'god' on a list. Buddhism is no exception. However, for Theravada Buddhism practiced by Sri Lankan Buddhists, there are no alternative rituals on-line. For Tibetan Buddhists, for example, there are hundreds of digital variations of repeated mantras and spinning prayer wheels online where one could use a moving animated image of a prayer wheel and recite the mantra to oneself (2012, Buddhism in a digital age). The internet is also able to magically transport people to Sri Lanka by taking devotees to the most sacred Buddhist temple in Sri Lanka, The Dalada Maligawa or the Temple of the Tooth in Kandy through virtual tours. There are also Buddhist pilgrimages advertised on-line for people to 
experience Sri Lankan Buddhism by visiting world famous Buddhist landmarks in Sri Lanka. There is also a lot of downloadable Buddhist material such as stories from the Dhammapada and stanzas for recitation in English. Furthermore, there are many websites devoted to teaching Pali and Sinhala for those who want to learn the language for religious purposes.

The use of English in the media facilitates access of the Buddhist sites to the global Buddhist community, including the UK. Additionally, magazines, newsletters, DVDs, Audio CDs of Buddhist rituals and practices are actively promoted by Sri Lankan Buddhist organisations and temples, which primarily use English as their language of communication. When Buddhist monks from Sri Lanka visit the UK, they address public religious meetings either in English or Sinhala; often however, unlike the Hindu Saints their individual consultations will be in Sinhala. Buddhist priests rarely interact with devotees in English unless they are unable to speak Sinhala.

Buddhist identity is a very sensitive subject in Sri Lanka, as seen from the incident of a British woman deported from Sri Lanka for having a Buddha tattoo on her arm. The BBC (22 ${ }^{\text {nd }}$ April 2014) reported that the woman 'had hurt others' religious feelings' and observed that Sri Lankan authorities "regularly take strict action against perceived insults to Buddhism." This kind of sensitivity towards Buddhism is not evident among Sri Lankan Buddhists in the UK and there is more accommodation to the cultural context of the UK where English is dominant. English is thus increasingly becoming one of the languages of Sri Lankan Theravada Buddhism in the UK and the use of it in the temples is not, as far as I'm aware, regarded by anyone as distasteful or disrespectful.

\subsection{Will English replace the sacred language(s) of Buddhism in the UK?}

Another question that the above discussion raises is whether the increased use of English for Buddhist activities will eventually result in language shift of the liturgical languages of Buddhism in the UK. As discussed above, a major challenge that the Sri Lankan community currently faces is the problem of language loss among the second generation Sri Lankans.

In Sri Lanka, Buddhism "is imbued in the culture and its influence on people and life-styles can be seen in daily life (Deegalle, 2008:29)." While Sinhala and Buddhism are taught at Buddhist temples and Buddhist cultural rituals are kept alive and continued through the celebration of cultural events, imparting Buddhism to the younger generations of Sri Lankans in the UK is a real challenge. For many young Sri Lankans, English is the first language, or 'mother tongue' and Sinhala is a second or foreign language. Many young Buddhists will be familiar with Pali and Sinhala through listening to their parents speaking the language or sometimes through memorising stanzas, but they will not be able to use the language for Buddhist discourse.

There are significant differences between the first and second generation of Buddhists in the UK. One of the main challenges for the first generation is that their 
children's understanding of Buddhism may be different from that of their own. According to Deegalle, unlike the first generation, the children may not see some of the rituals such as Buddha-pūjā, pirith chanting and cultural activities as "essential ingredients" for being proper Buddhists. He explains that for most parents, however, these traditional ceremonies are an integral part of their religious life. "The first generation learnt the religion by getting involved in Buddhist rituals and listening to sermons whereas the second generation learns the religion through meditation and reading" (Deegalle, 2008:29). As Smolicz observes, when a community's core values are seen as inessential, then it can result in the disintegration of cultural values.

Although there are evident changes taking place and challenges to maintaining Sinhala and Pali, it is difficult to predict that these languages will be replaced by English. As mentioned previously, the majority of Sinhalese in Sri Lanka are Sinhala speaking Buddhists and Sri Lankans only employ English as the language of communication for non-core cultural activities. Even though, according to Fishman (1965) second generation Buddhists in the UK may shift to English only monolingualism with no knowledge of either Sinhala or Pali, the continuation of Buddhist rituals in Sinhala and Pali will ensure the longevity of these languages and if second generation Buddhists want to continue to live as Buddhists, they will be forced to learn some Sinhala and to memorise stanzas from the Dhammapada in Pali, and in this way, the languages will continue to survive in the UK.

For Sinhala Buddhist immigrants in the UK their identity is closely tied to the Buddhist tradition which arrived in Sri Lanka in 250 BC (Perera, 1988:3) and its close connection to the sacred Pali canon. Pali is the liturgical language of Buddhism; it is held with great reverence because it is the language of the Dhammapada. Sinhala is the language of Buddhist theology and philosophy; it is highly regarded because it is the language of the Sinhalese and the majority language of Sri Lanka. For Sinhalese Buddhists both languages are deeply connected to their Buddhist identity and this is what draws Sri Lankans to temples and cultural centres. Parents are keen to preserve their Sinhala Buddhist identity and it is primarily this that "motivates parents to support temples, monks, their Sunday dhamma schools and special Buddhist festivals. Parents not only support monks financially and materially but also volunteer to teach in the Sunday dhamma schools" (Cush, 1990:44). All these strategies are ways of maintaining identity and ensuring that the second generation who are heavily influenced by Western culture in school "acquire a good Buddhist background." (Deegalle, 2008:27). The Sunday schools in temples provide children with the opportunity to learn Buddhism and Sinhala even if it is through the medium of English. This shows that Buddhism, Sinhala and Pali are core cultural values for Sri Lankan Sinhala people in the UK. Evidence of the vitality of Theravada Buddhism is also seen in the steady increase of Sri Lankan Buddhist temples in the UK, at a time when Christian seminaries are struggling to recruit new brothers to the priesthood. This may be because the ethnic core values are threatened by assimilation to the new culture. 
However, as Tilakaratne (2012:141) explains, it is only inevitable that "the nature of diaspora Buddhism will have to change with the second and third generation of migrants assimilating more into the host country's culture and lifestyle". The role of the clergy as well as the media in this process is important; Buddhists temples offer many Buddhist programmes such as weekly and monthly meditations as well as series of sermons in both English and Sinhala and websites offer many free resources of Theravada Buddhism in the form of audio visual material, which enable devotees to listen or watch Buddhist rituals as they are performed in the original Pali language, which "reemphasizes their belief in the efficacy in the sound of the sacred language Pandharipande 2013:426)." Through these means it will be possible for the media to maintain the function and transparency of Pali and Sinhala.

\section{Conclusion}

This study aimed to discover whether globalisation and the new cultural context had an effect on language use and maintenance of the languages of Buddhism for the Sri Lankan Buddhist community in the UK, with regard to previous research and theory which discuss how socio-political pressures can elevate language(s) to the status of core values in the diaspora. As the discussion showed, distinct languages were used in Buddhist rituals; Pali for chanting and prayers; Sinhala for talking to the clergy and English for non-core cultural activities. Although this is not a big use, it is a significant use, as it shows an expansion of domain functions for English within the religious domain. The role of English is expanding to slowly become a prominent language in Buddhist events being used at some of the important rituals such as the annual rain retreat and New Year celebrations.

It was also found that the use of English is sanctioned and authenticated by the Buddhists priests themselves who have the authority to use, reject, and prohibit certain practices. They sanctioned this use through using the language for sermons and explanations and also by recording sermons for download on the internet by users. Furthermore, use of English for Buddhist practice was authenticated through translations of Buddhist chantings and prayers and authorising the production and sale of audio CDs and DVDs of Theravada Buddhist songs containing mixed Pali and English verses.

Likewise, it was also seen that the media plays an important role in connecting Buddhists or those interested in Buddhism together with Sri Lankan Buddhist communities all over the world as well as in the UK through the dissemination of Buddhist content. Finally, it must be stated that the findings show the way in which language change within the Sri Lankan Buddhist community demonstrates how English has infiltrated into a new domain and is creating conflicting identities within the Sinhala Buddhist community as well as causing English itself to change in the way that it is used in terms of vocabulary and new idiomatic uses. 


\section{References}

Anthony, L. (2014). AntConc: A freeware concordance program for Windows, Macintosh OS X, and Linux. Retrieved from http://www.antlab.sci. waseda.ac.jp/software.html

BBC. (2002). Theravada Buddhism. Retrieved from http://www.bbc.co.uk/religion/religions/buddhism/subdivisions/theravada_1.shtml (Last accessed 15.06.2015).

Bluck, R. (2006). British Buddhism: Teachings, practice and development. London: Routledge.

Buddhist door media (2014) Abaya Gatha Retrieved from http://audio.buddhistdoor.com/eng/play/1634 (Last accessed 15.06.2015).

Buddhism in a digital age (2012). Retrieved from http://buddhismnewmedia.blogspot.co.uk/2012/03/buddhist-ritual-online-mantraand.html (Last accessed 15.06.2015).

Bourdieu, P. (1991). Language and symbolic power. Cambridge: Basil Blackwell.

Cousins, L. S., (1994). Theravaada Buddhism in England. In Buddhism into the Year 2000: International Conference Proceedings. Bangkok, Thailand: Dhammakaaya Foundation, 141-150.

Cush, D. (1990). Buddhists in Britain Today. Norwich: Hodder\& Stoughton

Deegalle, M. (2008). Promoting Buddhism in the UK: Sri Saddhatissa International Buddhist Centre's Contribution to British Buddhism. In M.

Deegalle (ed.) Dharma to the UK: A centennial celebration of Buddhist legacy. London: World Buddhist Foundation. 180-230.

Department of Census and Statistics Sri Lanka (2014). Sri Lanka census of population and housing 2011. Retrieved from

http://www.statistics.gov.Ik/PopHouSat/CPH2011/index.php?fileName=pop43\&gp=A ctivities\&tpl=3 (Last accessed 15.06.2015).

De Silva, K. M. (1981). A history of Sri Lanka. Oxford: Oxford University Press.

Dharmadasa, K. N. O. ( 1967) Spoken and written Singhalese: a contrastive study. M.Phil thesis. University of York.

Fernandez, S. and M. Clyne (2007) Tamil in Melbourne. Journal of Multilingual and Multicultural Development, 28(3): 169-187. Doi10.2167/jmmd488.0.

Fernando, C. (1977) English and Sinhala bilingualism in Sri Lanka. Language in Society, 6: 341-60.

Fishman, J.A. (1965). Language maintenance and language shift: the American immigrant case within a general theoretical perspective. Sociologus 16(1):19-39.

Fishman, J.A. (1966). Language loyalty in the United States: The maintenance and perpetuation of non-English mother tongues by American ethnic and religious groups. The Hague: Mouton. 
Fishman, J.A. (1972). Domains and the relationship between micro- and macrosociolinguistics. In J. Gumperz and D. Hymes (eds.), Directions in sociolinguistics.New York: Holt Rinehart and Winston, 435-453.

Gair, J. W. (1968) Sinhalese diglossia. Anthropological Linguistics, 10, 8: 1-15.

Gair, J.W. (1998) Studies in South Asian linguistics - Sinhala and other South Asian languages. Oxford: Oxford University Press

Gunasekera, M. (2005). The Post-Colonial identity of Sri Lankan English. Colombo: Katha Press.

Gunesekara, A. M. (1891) A comprehensive grammar of the Sinhalese language. Colombo: Sri Lanka Sahitya Mandalaya

Hughes, J. (1987) Buddhist monks and politics in Sri Lanka. Paper presented at the Spring Institute for Social Science Research. University of Chicago. Retrieved from http://www.changesurfer.com/Bud/Sri/Sri.html (Last accessed 15.06.2015).

Ludowyke, E. F. C. (1956) The footprint of the Buddha. Colombo: Buddhist Cultural Centre.

Perera, H.R. (1988) Buddhism in Sri Lanka: a short history. Kandy: Buddhist Publication Society.

Smolicz, J.J. (1981). Core values and cultural identity. Ethnic and racial studies 4(1): 7590.doi:10.1080/01419870.1981.9993325.

Smolicz,J.J. (1991). Language core values and cultural identity in Australia: some polish, welsh and Indian minority experiences. Phillipine Quarterly of Culture and Society, Vol.19 (2):107-134.

Vandana: the album of Pali devotional chanting and hymns. Retrieved from http://www.buddhanet.net/pdf_file/vandana02.pdf (Last accessed 15.06.2015).

Pandharipande, R.V. (2010). Authenticating a tradition in transition: language of Hinduism in the US. In T. Ominiyi (ed.) The Sociology of language of religion: change, conflict and accommodation. New York: Palgrave MacMillan. 58-83.

Pandharipande, R. V. (2013). Language of Hinduism in the US diaspora. World Englishes, vol 32(3): pp.417-428.

Rayson, P. (2014) Log Likelihood calculator. Retrieved from http://ucrel.lancs.ac.uk/llwizard.html Last accessed 15.06.2015.

Senaratne, C. (2008). Sinhala English code mixing in Sri Lanka. Netherlands: Lot publications.

The Buddhist TV Sri Lanka. (2014) Retrieved from http://www.youtube.com/watch?v=Qsih0VIdilw\&list=PLOjrj_IMOEYprAJ6gngT36Z6K6 u3cQG73\&index=74 (Last accessed 15.06.2015).

The Pali Text Society's Pali-English Dictionary. (2014) Retrieved from http://dsal.uchicago.edu/dictionaries/pali/ (Last accessed 15.06.2015).

Thomason, S. G. (2001) Language contact: an introduction. Edinburgh: Edinburgh University Press.

Tilakaratne, A. (2012). Theravada Buddhism: the view of the elders. Honolulu: Hawa'I University Press. 
